\title{
Nature Ecocriticism: The relation between Revolution Industry 4.0 and Nature in Heyward's Crazy Little Heaven.
}

\author{
Bambang Purwanto \\ \{bambangpurwanto@mail.unnes.ac.id\} \\ Universitas Negeri Semarang, Indonesia
}

\begin{abstract}
Human is intertwined with the environment. A human could not separate from the environment; they formed as a circle. The environment provides natural resources for the improvement in Industry, especially the revolution industry at present. How about humans right now? Do they still care about the environment and culture as a part of their life? Ecocriticism is a theory to expand our understanding of the environment. Eco critics read literature from the nature perspective. This present research is about Heyward's Crazy Little Heaven, a traveler who travels around Indonesia. The point in that novel is his journey from Samarinda to Pontianak. He found the beauty of Indonesia and it answers about what should human does in this Revolution Industry 4.0. Readers could find about part of Indonesian nature, part of Indonesia's culture and living harmony between people and nature in Crazy Little Heaven. This novel talks about the real Indonesia that is what Heyward said.
\end{abstract}

Keywords: Natural Resources, Ecocriticism, Eco critics, Revolution Industry, Living Harmony.

\section{INTRODUCTION}

"Hey, do not throw that rubbish into the street cause it can kill you!" This statement is rather funny for some people, but we will realize it if we know that it is a quotation for making living harmony. Some people usually blame the earth when a tsunami, earthquakes, and natural disasters come to them but people must realize they are the cause of the natural disaster. Jeremy Hance [1] mentioned nature through his article for Earth Day that every human, of course, needs to survive. Our earth has given us everything, such as food, water, medicine, and all-natural resources for our life. We can see the example from them, such as freshwater. Here, of course, there is no physical substance humans require more than freshwater: without water, we can only survive a few hellish days. Another sampling is fisheries; humankind has turned to the rivers and seas for food for at least 40,000 years but probably even longer. Today, amid concern of a global fishery collapse, more than a billion people in this lovely earth depend on fish as their primary source of protein, many of them among the global poor in some areas. Fisheries also provide livelihoods, both directly and indirectly, for around half a billion. Coral reefs, mangroves, and seagrass ecosystems provide nurseries for the world's fisheries, while the open ocean is used for migrating routes and hunting. Besides that, there is Health in which nature gives us a way to protect our body considering pollution so far. Recent research has found what 
nature-lovers have long expected: spending time in a green space, such as a park, provides benefits for one's mental and physical health. Exercising in a park, instead of inside a gym, has shown to provide mental health benefits as a greater sense of well-being.

The last sampling for the example is the arts. In this part, people could imagine poetry without flowers, painting without landscapes, or film without scenery. People could also Imagine if Shakespeare had no rose to compare Juliet to, or if William Blake had no Tyger to set alight. Mark Heyward could also write his travelling diary in his lovely novel because nature gives him everything. There is no question that the natural world has provided global arts with some of its greatest subjects. What we lose in nature, we also lose in art. That is why there is a strong and close connection between nature and humans.

Some people usually ask about learning of our nature or environment, and of course, we can say that Ecocriticism will help us to understand it. Ecocriticism is a study of representation nature in literary work, and of course, it also talks about the relation between our nature and literature [2] [3]. In Ecocriticism, we learn and analyze texts that illustrate environmental concern and examine it through its subjects. In this millennial era, sometimes we do not care about nature and we dig our nature by never pay attention to our earth. In the millennial era, we want to make us happy by having living harmony but we do not care about our earth or nature. Here, one aim of this research talks about the relation between Revolution Industry and Ecocriticism, especially in the subject of Crazy Little Heaven.

\section{METHOD}

There are many debates in literary concerning the identity and function of the subject [4]. In literary, there is a big question about Ecocriticism. How could we all find out that Ecocriticism is a term used for the observation and study of the relationship between the literature and the earth's environment. It takes an interdisciplinary point of view by analyzing the works of authors, researchers, and poets in the context of environmental issues and nature. Based on Sahu [2], Eco is a short of ecology, which is concerned with the relationship between living organisms on our earth. So, we can make it short that the relationship between humans and nature is reflected in literature.

Ecocriticism is a branch of literary criticism which has is being discussed worldwide as an interdisciplinary study of literature and the environment. It covers the study of subjects like science, literature, anthropology, sociology, psychology etc. and attempts to study the attitude of humankind. Here, we find out some ecocritics, such as Lawrence Buell, Cheryll Glotfelty, Simon C. Estok, Harold Fromm, William Howarth, and William Rueckert.

\section{Revolution Industry and Ecocriticism}

One goal in Revolution Industry 4.0 is about the improvement of technology. Andreja Rojko, one person who graduated from the University of Maribor [5] mentioned that industry 4.0 is a strategic transformation of industrial through the digitalization of new technologies. Industrial production is driven by global competition and the need for fast adaptation of production to the ever-changing market requests. Industry 4.0 is a promising approach based on the integration of the business and manufacturing processes. One thing that people in Industry 4.0 must remember is about the relationship between industry and nature. We cannot deny that nature will help humans to be a success in the industry as long as humans also care about nature. 
As people believed that nature is a part of human and vice versa. Absolutely, it could not be separated between both. Sometimes people ask about the connection between both humans and the environment. The environment will be stable when people care about it and of course, the environment will have a good impact on us. The relationship has been reflected through authors and poets with their writing. Variety novels, poems, stories, and other expressions of literature have been depicted. Crazy Little Heaven shows the connection between nature and humans. Ecocriticism explores the connection between cultural production and its environment. Mark Heyward, an Australian traveler, shows us that people must love and care for their families. He found one Heaven when he travelled to Indonesia. Nature and culture are two of the most awesome excellent as a result of the relation between humans and nature.

\section{RESULT AND DISCUSSION}

Tim Hannigan mentioned that Indonesia is strangely underrepresented on the "travel literature". The most traveler will love Indonesia, especially after they find out the beauty inside it. It is an archipelago that lies across the Equator and spans a distance equivalent to one-eighth of Earth's circumference. Its islands can be grouped into five big islands; Sumatra, Java, Borneo (Kalimantan), Sulawesi and Papua. In the early 21st century, Indonesia was the most populous country in Southeast Asia and the fourth most populous in the world. Mark Heyward travels to Indonesia, especially to Borneo, for teaching. For the first time, he never pays attention to the beauty in Borneo until he learned about the culture in Borneo. (Heyward 4-5)[6]

Heyward came to Indonesia in 1992 with a group of Tasmanian teachers in the coastal jungles of East Kalimantan. At first, he expected an adventure but he never finds out that Indonesia would change his life. Together with some friends of him, Fergie, Vonie Anto, Tim Harrington and Ray Rutherford, did an expedition to find the culture in Borneo. They travel around Borneo and they enjoy the culture there. They also go to Kersik Luwai, a forest reserve known for its wild orchids. In that part, it shows that they still love to find happiness by finding the beauty of nature. Their trip to Kersil Luwai symbolizes Ecocriticism in which they include in the process of relation. They do not care about the problems for their trip but they want to learn many culture differences with their own. They even find lamin, or we can call it as a longhouse where families live the old way. (Heyward 21) [6]

On their trip, they also meet Bugis. For them, this tribe initially from the south coasts of Sulawesi, is a famous seafaring people whose traditional trade as pirates has not been entirely left behind. Their skill as boat builders is legendary. (Heyward 41) [6]. They love fisheries until their boat goes to Singapore, where the famous Bugis Street, housed in that country. Not only in Singapore, but they also have a house in Malaysia and Thailand. This situation shows that human, of course, need nature as part of to survive. Australian finally know, they must love their nature or culture, so they belong to the earth.

One last experience is about love. Heyward had already been in love with Pinisi. He had the idea of the sea, especially the idea of the Pinisi with tall ships. He remembered his childhood in the old harbor town of Hobart. (Heyward 259) [6]. He also said his experience to look at pinisi, the wooden sailboats gliding on that distant blue line, passing beyond the outer reefs of Sangatta. He also looked at elegant sweeping lines, the wide-bellied hulls, the twin masts, double rudders and hand-sawn decking of those beautiful ships.

His own experiences made him love his heaven, Indonesia. Right now, he lives in Lombok with his wife and two children. Mark Heyward's condition finally shows that the relation between human and nature must be close. After twenty years of living travelling, and working in Indonesia finally he finds happiness although he must migrant from his country to Indonesia, 
but at least he finds his happiness. Not only in education, but he also enjoys to write his own experiences, makes music and one of his new hobby; walks in the hills. His new hobby shows us the closest relation between himself and nature.

\section{CONCLUSION}

To conclude, The writer would like to say that Ecocriticism engages us theory and practices. We may learn about nature or even conservation, but if we do not do kind of practices so we will be left behind. The study shows us nature will serve us everything as long as we also love nature as part of us. Heyward's way gives us the understanding that loving nature means we do everything to protect it.

\section{REFERENCES}

[1] J. Hance, "What does Nature give us? A special Earth Day article," Mongabay, 2011.

[2] G. Sahu, "Ecocriticism- Understanding the Relationship Between Literature and Environment in Indian English Novels," Sai Om J. Arts Educ., vol. 1, no. 1, pp. 23-26, 2014.

[3] S. Endraswara, SASTRA EKOLOGIS: Teori dan Praktik Pengkajian. CAPS (Center for Academic Publishing Servive), 2016.

[4] M. A. Semi, Metode penelitian sastra. Banddung: Angkasa, 1993.

[5] A. Rojko, "Industry 4.0 concept: Background and overview," Int. J. Interact. Mob. Technol., vol. 11, no. 5, pp. 77-90, 2017, doi: 10.3991/ijim.v11i5.7072.

[6] M. Heyward, Crazy Little Heaven: An Indonesian Journey. Sid Harta Publishers, 2012. 